\title{
FORMAL STRATIGRAPHY IN THE PLEISTOCENE OF FINLAND
}

\author{
PHILIP L. GIBBARD
}

\begin{abstract}
GIBBARD, PHILIP L. 1992. Formal stratigraphy in the Pleistocene of Finland. Bull. Geol. Soc. Finland 64, Part 2, 125-134.

The importance of the application of formal lithostratigraphical, biostratigraphical and chronostratigraphical procedures to the subdivision of Finnish Pleistocene sediment sequences and the need to define both regional and local stratotypes are discussed. The particular problems relating to the definition of stratotypes in areas that have been subjected to glaciation are addressed. Problems regarding nomenclature and correlation of Pleistocene sequences, largely arising from non-definition or unsatisfactory definition of stratotypes are illustrated with reference to the Saalian Stage of northern Continental Europe and some Finnish examples. Recommendations are presented to encourage and improve the selection and definition of stratotypes for Quaternary sediment sequences in Finland.
\end{abstract}

Key words: glacial geology, stratigraphy, stratigraphic units, stratotypes, type localities, Pleistocene, Finland.

Philip Gibbard, Subdepartment of Quaternary Research, Botany School, University of Cambridge, Downing Street, Cambridge CB2 3EA, England.

\section{Introduction}

Research during the last twenty years in Finland has increasingly demonstrated that the Quaternary sequence apparently represents considerably more of Pleistocene time than previously envisioned. This development has arisen from the identification of multiple till sequences, interglacial and interstadial organic sediments as well as non-glacial cold-climate sediment sequences and soils. This increasing complexity is accompanied inevitably by an expansion in terms required to refer to individual units. However, the terms that are becoming established in the new literature, together with the concepts adopted to subdivide the sequences, are in some cases not ideal. The nomenclature currently in use has evolved from a combination of long-established practice for those units and features that have been known for many years, supplemented by field terms and section logging practices for the new units recognised. These terms, although they may be implicitly understood and clear to individual practitioners familiar with the concepts represented, are not necessarily well-suit- ed for inter-regional correlation and international communication.

With these views in mind, this paper presents some thoughts on the need to apply internationally accepted, standardised stratigraphical principles to Finnish Quaternary sediment sequences. These principles represent a concensus agreed and established by the International Commission on Stratigraphy. The International Stratigraphic Guide (ISG) (Hedberg 1976) provides the basic reference for these principles in the form of a code. This guide clearly states that lithostratigraphical units (formations and members), chronostratigraphical units (stages and substages) and likewise biostratigraphical units (biozones) need to be clearly differentiated and moreover, should be firmly based on and specifically defined from actual stratotypes at type localities.

The objectives of these internationally-accepted stratigraphical procedures can be summarised as follows:

1) To subdivide and classify rock sequences and geological time;

2) To provide an unambiguous basis for such sub- 
divisions;

3) To facilitate correlation within and between different geographical areas;

4) To facilitate communication.

In this paper the advantage in increased rigour and scientific precision in adopting the ISG recommendations is presented.

First, the classical subdivisions of the Quaternary in northern Europe are considered, to examine how these subdivisions, particularly those used for chronostratigraphical purposes, were erected and to what extent they now conform to the recommendations of the International Stratigraphic Guide.

Secondly, the particular problem of the subdivision of the Saalian Stage in northwest Europe to illustrate the need for precision in the definition of unit and boundary stratotypes is presented.

Thirdly, the problems of the Finnish Quaternary sequence are discussed to emphasise the need to the define that sequence in accordance with the ISG recommendations.

Finally, some recommendations for the selection and definition of national stage and substage stratotypes, their placement as far as possible in non-glacial sediment sequences and the need to compile a reference document of such sites are presented

\section{Stage-status stratigraphical units in northern Europe}

The Pleistocene Period is characterised by large amplitude climatic fluctuations, one of the most striking consequences of which are intervals of expansion of ice sheets across the whole of Finland into lowland present-day temperate regions. Because these massive expansions of glacial ice produced such a major impact on the land surface, they inspired geologists in the 19th and early 20th centuries to attempt a subdivision of 'Ice Age' time using these events. This led pioneers of Quaternary stratigraphy, such as Geikie (1874), to be already recognising 'glacial' and 'interglacial' events in the late 1800 's. The terms glacial and intergla- cial period or stage are still persistently in use, in spite of repeated pleas by several authorities that they should be abandoned.

These views have arisen because the terms glacial, interglacial, stadial and interstadial were originally and often still are used in place of the terms stage and substage respectively. There is a fundamental difference between these terms. Glacial and interglacial etc. are geological-climate units, as defined by the American Commission on Stratigraphic Nomenclature (1961) and are based on climatic events inferred from geological sequences. As such they are used almost exclusively in the Pleistocene. In practice, they can only be truly valid in glacierised areas, for which they were originally conceived. An additionally significant problem is that the boundaries of such climatically-determined units will almost certainly not be synchronous across large areas, especially in continental sequences. This is because climatic changes must very often be strongly-influenced by local climate and geographical factors. In contrast, stage and substage are chronostratigraphical units, the function of which is clearly defined by the International Stratigraphic Guide. A stage is a chronostratigraphical unit of relatively minor rank, considered to be the most suitable for interregional correlation. The boundaries of stages are ideally isochronous surfaces between fixed points both within and beyond the type area. (cf. Hedberg 1976). In deep-ocean cores stages have been defined on the basis of oxygen isotope curves, which are also linked to climatic changes. Though it seems likely that the boundaries of these isotope stages are not precisely synchronous throughout the world's oceans, they nevertheless may be more nearly so than the onset of the 'glacial' and 'interglacial' units recognised in continental sequences.

The use of geological-climatic subdivisions 'glacial', 'glacial stage', 'glaciation' and equivalents have been repeatedly discouraged by West $(1963,1984,1989)$ in favour of the term 'cold stage' (Gibbard \& Turner 1990). Lüttig (1965) went further by suggesting abandonment of the these and the term interglacial etc., and replacing them with the words cryomere and thermomere re- 
spectively. Lüttig's proposals have not, however, found general acceptance. Nevertheless, they are still applied occasionally. For example, they were recently advocated by Zubakov \& Borzenkova (1990) who adopted these terms as the basis of a highly theoretical complex hierarchy of climatebased stratigraphical units that are of little practical utility.

A further complication to this discussion arises from recent proposals by the Norwegian Committee on Stratigraphy (Nystuen 1989) for a new series of stratigraphical subdivisions termed diachronous units (time-transgressive event stratigraphy). They are divided into episodes and events. These new units are intended to represent the time span of a geological event characterised by a specific geological process. For use in the Pleistocene such units may represent a glaciation, a marine trangression or a period of aeolian sand deposition, for example. They are clearly then very similar to the geological-climate terms glacial and interglacial. However, as Bouchard et al. (1990) have emphasised, if diachronous units are applied, it is vitally important that an unambiguous distinction is made between any particular event (e.g. glacial advance or retreat) or episode (a glaciation) and the time (chronostratigraphical stage or geochronological age) during which these events or episodes occurred. As an illustration, this means that the main Weichselian glaciation (Weichselian Glacial Episode), that begun in Finland at c.75ka and ended by $8.9 \mathrm{ka}$, began in the Late Weichselian Substage and ended in the early Flandrian Stage (Holocene Epoch).

It has been argued that glacial deposits must be known from any particular period in order to define a particular 'glacial' stage or event. However, it is not always possible to unequivocally demonstrate glaciation, particularly in the Early and early Middle Pleistocene. Moreover, the 'glacial' time intervals themselves are virtually never represented in the geological record exclusively by glacial deposits. All recognised cold stages include sediments laid down under periglacial, non-glacial and indeed even short-lived (interstadial) equitable climates, particularly outside the actual area of con- temporary glaciation.

In keeping with a tradition begun by Penck \& Brückner (1901-1909) in the Alpenvorland, cold or 'glacial' stages in northern and central Europe have nevertheless been named from the occurrence of glacial, glaciofluvial and glaciolacustrine deposits. The earliest, and still widely-used, terms for cold stage stratigraphical units were those proposed by Penck \& Brückner; Würm, Riss, Mindel, Günz. Ever since these names have been applied in many parts of the world far from their original geographical area, not as proper chronostratigraphical terms but simply as concepts with a broadly understood but undefined meaning (i.e. last, penultimate, antepenultimate glacial period etc.). Even in their type region, the terms were attached in a generalised way to suites of glacial and glacifluvial deposits in several valleys. Only in 1983 was the chronostratigraphical term Würmian formally defined by Chaline \& Jerz and assigned to a measured and well-studied stratotype at Samerberg in southern Germany. The remaining terms have yet to be formal defined, and, perhaps more importantly, there no longer seems to be a concensus of opinion that the ages and stratigraphical position of the glacial and glacifluvial deposits associated with the terms Riss and Mindel by Penck \& Brückner in the Alpenvorland type region necessarily correspond chronologically with the concepts assumed and used by Quaternary geologists and particularly archaeologists in other parts of the world.

This practice of naming major episodes of glaciation, usually after the names of local rivers, was extended by Keilhack in the 1920's to the area of the North European Plain affected by the Scandinavian ice sheet on maps produced by the Preussische Geologische Landesanstalt (cf. Woldstedt 1929 p. 179). These terms, Weichsel, Saale and Elster, were only informally published and were not clearly associated with any defined type localities. Regrettably, this is still the case today.

As Gibbard \& Turner (1990) have emphasised, such terms as Saale and Elster have been applied indiscriminately for the purposes of both lithostratigraphy and chronostratigraphy; for example the expressions Saale I, II, III Grundmoräne, Saale- 
Hauptterrasse, Saalevereisung, as well as Saaleeiszeit. This was recognised as a problem by Dutch Quaternary stratigraphers early in the 1950's (Van der Vlerk 1953, Van der Vlerk \& Florschütz 1953, Van der Vlerk 1957, Van der Heide \& Zagwijn 1967). As a result they subdivided the Netherlands sequence into lithostratigraphical formations and began to use the terms Saalian (or Drenthian) and Elsterian to denote the cold stages as chronostratigraphical units. Likewise, terms such as Eemian and Holsteinian (Needian) were used to denote temperate (interglacial) stages.

In spite of this, in non-English speaking countries outside the Netherlands, the subdivision of the Pleistocene remains largely based upon the geological-climate units, contrary to the ISG recommendations (Table 1). In Germany, for example, the terms Glazial or Eiszeit and Interglazial or Warmzeit still predominate (e.g. Grube 1986). Likewise, the corresponding Finnish terms are jääkausi and interglaasiaali (Donner 1976). In common with the English terms 'glacial' or 'interglacial', these quasi-stage type subdivisions carry an implied climatic significance, whilst also including the chronostratigraphical implication of the term stage. In the light of modern knowledge that all the later Pleistocene cold periods include shorter warm climate events it is apparent that the continued use of climate-based terms is unfortunate. The fact that these terms are so strongly embedded in the literature means that it is unlikely that they will be discarded in favour of the more precise chronostratigraphical terms. However, the long term aim should be to replace geological-climate terms. This aim is more likely to be achieved in Finland, where this matter is currently being actively debated, than elsewhere in the non-English speaking world where geologists seem unconcerned about or unaware of these problems.

\section{Chronostratigraphy and climatic change}

In the geological community a consensus is now accepted that Pleistocene sequences should be divided chronostratigraphically into stages in com-
Table 1. Middle to Late Pleistocene chronostratigraphical stages of western central Europe and Finland (sources: Donner, 1976; Grube, 1981).

\begin{tabular}{|c|c|c|}
\hline English / Dutch & German & Finnish \\
\hline Weichselian* & $\begin{aligned} \text { Weichsel } & \{\text { Kaltzeit } \\
& \{\text { Glazial }\end{aligned}$ & Veiksel-jääkausi \\
\hline Eemian* & $\begin{array}{ll}\text { Eem } & \text { \{Warmzeit } \\
& \text { \{Interglazial }\end{array}$ & Eem-interglasiaali \\
\hline Saalian* & $\begin{aligned} \text { Saale } & \{\text { Kaltzeit } \\
& \{\text { Glazial }\end{aligned}$ & Saale-jääkausi \\
\hline Holsteinian* & $\begin{aligned} \text { Holstein* } & \{\text { Warmzeit } \\
& \{\text { Interglazial }\end{aligned}$ & $\begin{array}{l}\text { Holstein- } \\
\text { interglasiaali }\end{array}$ \\
\hline Elsterian* & $\begin{array}{c}\text { Elster }\{\text { Kaltzeit } \\
\text { \{Glazial }\end{array}$ & ?Elster-jääkausi \\
\hline $\begin{array}{l}\text { Cromerian*/ } \\
\text { 'Cromerian Com }\end{array}$ & $\begin{array}{l}\text { 'Cromer Komplex' } \\
\text { plex'* }\end{array}$ & $?$ \\
\hline
\end{tabular}

*Stage with formally-defined stratotype(s)

mon with the rest of Phanerozoic time. Nevertheless, Quaternary chronostratigraphic subdivision has become almost inextricably linked with geological-climate units. To justify this it has been claimed that major climatic changes during the Quaternary, such as those recorded in the deep ocean oxygen isotope curves, are globally synchronous or virtually so compared to the dating precision achievable for chronostratigraphical boundaries defined for earlier geological periods.

However, as Zagwijn (1985) and De Jong (1988) have emphasised, it is no longer practicable in Pleistocene stratigraphy to assign a new stage to each climatic event. This is because the scale of individual events varies considerably, and because the number of events now known is so high. These authors have therefore stressed the need for complex stages, i.e. intervals of time containing several climatic oscillations at the currently detectable scale. The cold stages of the later Pleistocene are typical examples of this principle, particularly the early part of the Weichselian (Woillard 1975, 1978; Mangerud 1991) and the Saalian (Zagwjn 1986, Gibbard \& Turner, 1990).

The classification and subdivision of the Saalian in northern Europe illustrates problems that derive directly from the lack of a formal and agreed 
stratotype for this stage (Fig. 1). Although originally recognised in eastern Germany, much of the detail of events during this stage has been established in the Netherlands and neighbouring north Germany (Grube 1981, Ter Wee 1983, Ehlers et al. 1984, Urban et al. 1989). As already mentioned, it is now fully accepted that cold stages include not only prolonged intervals of cold climate accompanied on occasions by glaciation, but also shorter intervals of relatively warm climate, often referred to as interstadials. Such stadial and interstadial intervals have frequently been designated, usually informally, as substages, but the problems of definition and synchroneity of substage boundaries are essentially the same as for stages. In the Netherlands two such intervals or episodes, the Hoogeveen Interstadial and the Bantega Interstadial are recognised in the early part of the Saalian (Zagwijn 1973; cf. also the 'Belvédère Interglacial' of Vandenberghe, personal communication). The onset of the Saalian is taken as the point at which cold-climate conditions, indicated by renewed dominance of open ground plant taxa in pollen diagrams, mark the end of the Holsteinian temperate Stage. However, in northern Germany, particularly in the former German Democratic Republic, in what is classically thought of as the undefined type area of the 'Saale' of Keilhack, one of these intervals of warming, probably equivalent to the Hoogeveen Interstadial, is regarded as of full interglacial status and has been defined as the Dömnitz or Dömnitzian 'Stage' (Cepek 1967, 1986). The Dömnitzian is separated from the Holsteinian by a short interval termed the Fuhne Stadial . A similar stratigraphy has been recognised at Wacken in Schleswig-Holstein (Menke 1968) and at Helmstedt (Urban et al. 1989) in western Germany. Cepek (1986) includes the 'Dömnitz interglacial', the 'Fuhne glacial period (?)', together with the 'Holstein interglacial (sensu stricto )' within a 'Holstein Complex'. The base of the Saalian Stage, as recognised in eastern Germany (exGDR), is therefore younger than in the Netherlands. This state of affairs is clearly not satisfactory and would not have arisen if a stratotype for the Saalian Stage had been properly and formally de-
Netherlands

Germany

\section{Eemian}

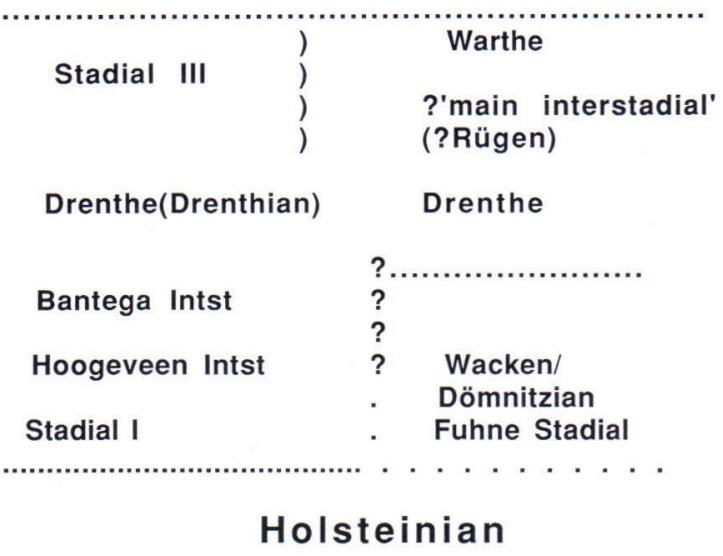

Fig. 1 Saalian Stage chronostratigraphy in the Netherlands and Germany, based on sources quoted in the text.

fined. Fortunately, the 1992 meeting of the INQUA Subcommission of European Quaternary Stratigraphy agreed to define the base of the Saalian at the end of the Holtenian, as in the Netherlands.

\section{Stratotypes}

When Pleistocene sequences are divided chronostratigraphically into stages, it is vital that type localities be presented from which these units can be defined. The ISG requires that all stratigraphical units be formally-defined from type localities or stratotypes. Stratoypes may be of three basic kinds:

(a) Unit stratotypes, i.e. at localities where individual units are defined;

(b) Boundary stratotypes, i.e. at localities where a particular boundary is defined;

(c) Composite stratotypes, i.e. at localities where both boundary and unit stratotypes are recognised.

By far the most consistent and detailed definition of stratotypes in Europe has been in the Netherlands. However, both the Dutch, and to a lesser extent the British, have defined cold stages and 
substages by reference to their position intermediate between temperate (interglacial) stages or substages. The actual boundaries between these stages have predominantly been defined using palynology at the point where 'interglacial' type vegetation changes to that of a cold stage type. The ends of cold stages are automatically defined by the base defined for the immediately following temperate stage.

Although they are abundant in Finland, glacial deposits are not well suited as national or international cold stage or substage stratotypes for a variety of reasons. Most importantly, it is very difficult to determine the amount of time any particular glacial deposit might represent. Secondly, it can be difficult to correlate glacial deposits over large areas (particularly extra-regionally), since they seldom contain material that can be used biostratigraphically or for geochronology. Thirdly, glacial deposits frequently rest on an eroded or glaciallymodified surface, and, therefore, inevitably there will have been a loss of information, at best a short time gap and in the worst cases an hiatus of thousands or even millions of years. For these reasons it is apparent that cold stages and indeed substages should ideally be defined in non-glacial sequences, where additional detail of stratigraphical significance is potentially available. Clearly this is not possible in Finland. However, it is possible to define boundaries and stratotypes in the most complete sedimentary sequences, where the succession contains unambiguous sedimentary relationships (e.g. Bouchard et al. 1990).

Throughout much of the later Middle and Upper Pleistocene there are few formally defined boundary stratotypes in north and western Europe outside the southern North Sea basin, for cold stages and substages. This is a serious lack of precision in formal chronostratigraphy and is contrary to the strong recommendations of the ISG and the formal International Commission on Stratigraphy (ICS) guidelines (Cowie et al., 1986).

A boundary stratotype is a locality at which the base of a stage (and thus by inference the top of the previous stage) is defined in a sediment sequence.The identification of stage and other time significant boundaries in rock sequences has been much discussed by stratigraphers in connection with marking the actual boundary line either notionally or actually with a 'golden spike' (see discussion in Holland 1986). Ideally such boundaries should be located in continuous sediment sequences, but in practice it may be difficult. There is however, ample potential for the definition of such boundary points. At many sites in western Europe stage boundaries occur in lacustrine and fluvial sediments, e.g. the Eemian/Weichselian boundary is recorded at Samerberg (Chaline \& Jerz 1983) and at La Grande Pile (Woillard 1978). Similarly in Britain, the Hoxnian / Wolstonian boundary is identified in the pollen analyses of Turner (1970) and the Wolstonian / Ipswichian boundary is recognised by West (1957) at the Ipswichian Stage stratotype at Bobbitshole. Comparable sites that could be used for this purpose also exist on the Continent for other stage boundaries. It should be emphasised that there is no formal procedure for defining the top of a stage. The time-period of a stage is deemed to continue until the onset of the next-youngest stage defined.

\section{Stratigraphical problems in the Finnish Qua- ternary}

In this section five examples of problems arising from a lack of application of formal stratigraphical approaches to Pleistocene stratigraphy in Finland are presented. The order of these examples is not significant. Each example is selected to illustrate a particular area of difficulty or ambiguity.

\section{Salpausselkä Ridges}

The Salpausselkä End Moraines are possibly the best known moraine ridges in the world and are central to any understanding of ice recession during the Late Pleistocene in Finland (Glückert 1986). In general they are recognised by their external form, i.e. as morphological units, and have been assigned ages on the basis of their relation- 
ship to the varve chronology and to sediments filling kettle hole lakes in their uppermost surface (Donner 1971). Excavations in the Salpausselkäs expose a complex lithostratigraphy within the ridge-like landforms at most localities. The Salpausselkä Moraines are therefore both morphostratigraphical and lithostratigraphical units, although the two types of evidence provide different stratigraphical information. For this reason it is important to differentiate between the landform and its internal depositional sequence.

\section{Late Pleistocene Baltic Sea sediments}

During the Late Weichselian and Flandrian Stages much of southern and western Finland was submerged beneath the Baltic Sea or its lacustrine equivalents (e.g. Donner 1965). The sedimentary sequences that accumulated beneath the waters of the Baltic have provided the evidence to recognise four major phases in the Late- and Post-glacial Baltic: respectively, the Baltic Ice Lake, the Yoldia Sea, the Ancylus Lake and the Littorina Sea. These stages are based on the interpretation of microfossil assemblages from the sediments (almost exclusively pollen and diatom assemblages). Radiocarbon dating of events associated with the changes in the assemblages has allowed the changes to be used chronologically within the basin (e.g Eronen 1974).

The terminology used to subdivide the Baltic sediment sequences has evolved from the stages recognised e.g. the Littorina clays etc. The result is not a correct lithotratigraphical subdivision, but a combination of litho-, bio- and chronostratigraphy that could potentially lead to confusion.

\section{Till-covered eskers}

It is now apparent that in many parts of the country glaciofluvial sediment bodies are overlain by glacial diamicton. Although a landform cannot always be identified, these sequences are very frequently referred to as 'till-covered eskers"' (e.g. Niemelä \& Tynni 1979). Clearly, this descriptive terminology implies both genesis and morphology of the sediment beneath the till. In many cases this may be correct, but the assumption clearly obscures objective description of the sedimentary unit. It once again mixes morphology and lithology.

\section{Interglacials and interstadials}

The recognition of relatively warm climate events in the Finnish Pleistocene is a relatively new phenomenon. The basis for the identification of these events is the fossil assemblages present in the sediments (Korpela 1969, Aalto et al. 1983, Donner 1983, Forsström 1982, Hirvas \& Kujansuu 1979, Gibbard et al. 1989, Grönlund 1991). Considerable discussion has taken place in recent years as to the climatic significance of individual sequences. However, generally attempts have been made to equate these sequences with the relatively well-established events in central western Europe (e.g. Grönlund 1991). Arguments based upon biological assemblages are clearly restricted by the biotal changes at ecotonal boundaries. This is especially important in the interglacial sequences in which assemblages in temperate western Europe differ markedly from the predominantly boreal assemblages in Finland.

Nevertheless, interglacial sequences have been correlated mostly with the last or Eemian Stage interglacial event using palaeontological assemblages. These correlations have been supported by absolute dates and other evidence. The need to define one or more local stratotype sequences is however, vital in order to provide an unambiguous reference sequence for this event and its palaeontological succession in the region. This is particularly important for older deposits where doubt over the age and equivalence must be considerable in view of the complexity of events known from other parts of the world.

\section{Multiple till sequences}

The extensive investigations by the Geological Survey throughout the country, but particularly in Lapland by Hirvas and co-workers (Hirvas \& 
Nenonen 1987, Nenonen 1986, Hirvas 1991) and similar investigations by Saarnisto \& Peltoniemi (1984) in eastern Finland and Aario \& Forsström (1979) in northern Finland have resulted in the recognition of multiple till sequences in many areas. The sequences have been interpreted as indicated repeated glacial events. In some areas it has been possible to relate these events to non-glacial fossiliferous sediments and thereby develop a relative chronology.

These important discoveries have revolutionised concepts of stratigraphy in Finland and precipitated the need for consideration of a more formal stratigraphical framework. This framework is required because, at the time of writing, the till units lack stratotypes and have not been assigned unit names in keeping with the ISG recommendations.

As these short summaries illustrate there seems to be much confusion over the nomenclature adopted and the separation of stratigraphical evidence into its component parts for the sake of greater clarity and precision in stratigraphical correlation. The adoption of formal stratigraphical classification provides a solidity, strength and resilience to the stratigraphical sequence in any area by allowing modifications to be made to the structure or order, yet obviates the need to change the entire structure if changes occur. Furthermore, the systematic application of internationally standardised nomenclatoral systems simplifies and clarifies communication both within the country and beyond. Clearly any terms adopted will require translation and some modification from the English for use in the Finnish or Swedish languages. What is important however, is the recognition of the need to adopt a stricter, more systematic approach to stratigraphical concepts

\section{Recommendations}

The following recommendations arise from the examples of confusion quoted above and from general experience in Quaternary stratigraphical prob- lems in related glaciated regions in Europe and beyond (cf. Gibbard \& Turner 1990).

1. It is vital that stratotypes are defined for all stages and substages. Priority should be given to locating stage stratotypes equivalent to the Weichselian and Saalian of central Europe. Stratotypes for interglacial stages such as the Tepsankumpu event (Hirvas 1991) are urgently needed. Haapavesi (Forsström et al. 1988) or Evijärvi (Eriksson et al. 1980) might be appropriate as parastratotypes for southern Finland last interglacial (Eemian Stage equivalent) sequences. The sediment sequences in Pohjanmaa offer possible pre-Eemian localities for stratotypes for cold stage deposits.

2. Wherever possible, boundary stratotypes should be placed in continuous sediment sequences, or at minor erosional hiatuses. In general, lacustrine sequences appear to provide the most unambiguous continuous sedimentary records on the continents and have the added advantage of generally yielding good biostratigraphical evidence.

3. Sound lithostratigraphy is required for many of the sedimentary successions, particularly where they are buried by younger deposits, as stressed by Bouchard et al. 1990. Of particular importance however, is the need to fully understand the sedimentology of a sediment unit before its full stratigraphical significance can be assessed.

4. It is preferable that any national or regional stratotype localities that are selected be, as far as possible, in non-glacial sediment sequences since they include potentially a wider range of information that can be used for interregional and possibly land/ocean correlations.

5. A reference document or catalogue of all stratotypes should be compiled, in which sites could be described, subdivided and defined in a uniform way.

Acknowledgements. I am grateful to Dr C. Turner for permission to reproduce material from our joint paper (Gibbard \& Turner, 1990). I would also like to thank Dr V.-P. Salonen for his encouragement and discussions. 


\section{References}

Aalto, M., Donner, J.J., Niemelä, J.\& Tynni, R., 1983. An eroded interglacial deposit at Vimpeli, south Bothnia, Finland. Geological Survey of Finland Bulletin 324, 1-41.

Aario,R.\& Forsström,L. , 1979. Glacial stratigraphy of Koillismaa and North Kainuu, Finland. Fennia 157, 1-49.

American Commission on Stratigraphic Nomenclature, 1961. Code of stratigraphic nomenclature. Bulletin of the American Association of Petroleum Geologists 45, 645-660.

Bouchard, M.A., Gibbard, P., Salonen, V.-P., 1990. Lithostratotypes for Weichselian and pre-Weichselian sediments in southern and western Finland. Bulletin of the Geological Society of Finland 62, 79-95.

Cepek, A.G. , 1967. Stand und Probleme der Quartärstratigraphie im Nordteil der DDR. Berichte der Deutschen Gesellschaft für geologische Wissenschaft A, Geologie, Paläontologie 12, $375-404$.

Cepek, A.G., 1986. Quaternary stratigraphy of the German Democratic Republic. Quaternary Science Reviews 5, 359-364.

Chaline, J. \& Jerz, H., 1983. Proposition de création d'une étage würmienne par la sous-commission de stratigraphie du Quaternaire européen de l'INQUA. Bulletin de l'Association française pour l'Étude du Quaternaire (N.S.) 16, 149—152.

Cowie, J.W., Zeigler, W., Boucot, A.J., Bassett, M.\& Remane, J., 1986. Guidelines and statutes of the International Commission on Stratigraphy (ICS). Cour. Forschung -Inst. Senckenberg. $83,1-4$.

De Jong, J., 1988. Climatic variability during the past three million years, as indicated by vegetational evolution in northwest Europe and with emphasis on data from The Netherlands. Philosophical Transactions of the Royal Society of London B 318, 603-617.

Donner, J.J., 1965. The Quaternary of Finland. In: Rankama, K.(ed.) The Quaternary. 1 J.Wiley \& Sons: London. 199272.

Donner, J.J., 1971. Towards a stratigraphical division of the Finnish Quaternary. Commentationes Physico-Mathematicae $41,281-305$.

Donner, J.J., 1976. Suomen kvartäärigeologia . Helsingin Yliopisto. Moniste N:o 1

Donner, J.J., 1983. The identification of Eemian interglacial and Weichselian interstadial deposits in Finland. Annales Academiae Scientiarum Fennicae Series A III GeologicaGeographica 136, 1-38.

Ehlers, J., Meyer, K.-D., \& Stephan, H.-J., 1984. The preWeichselian glaciations of Northwest Europe. Quaternary Science Reviews 3, $1-40$.

Eriksson, B., Grönlund, T., \& Kujansuu, R., 1980. Interglasiaalikerrostuma Evijärvellä, Pohjanmaalla. Geologi 32, 65-71.

Eronen, M., 1974. The history of the Littorina Sea and associated Holocene events. Commentationes Physico-Mathematicae $44,1-79$.

Forsström, L., 1982. The Oulainen interglacial in Ostrobothnia, western Finland. Acta Universitatis Ouluensis Series A Scientiae Rerum Naturalium 136, 1-123.
Forsström, L., Aalto, M., Eronen, M. \& Grönlund, T., 1988. Stratigraphic evidence for Eemian crustal movements and relative sea level changes in eastern Fennoscandia. Palaeogeography, Palaeoclimatology Palaeoecology 68,317335.

Geikie, J., 1874. The great ice age and its relation to the antiquity of Man. W. Isbister \& Co.: London 575p.

Gibbard,P.L.\& Turner, C., 1990. Cold stage type sections; some thoughts on a difficult problem. Quaternaire 1, 33-40.

Gibbard, P., Forman, S., Salomaa, R., Alhonen, P., Jungner, H., Peglar, S., Suksi, J. \& Vuorinen, A., 1989. Late Pleistocene stratigraphy at Harrinkangas, Kauhajoki, western Finland. Annales Academiae Scientiarum Fennicae Series A III Geologica-Geographica 150, 1-36.

Glückert, G., 1986. The First Salpausselkä at Lohja, southern Finland. Bulletin of the Geological Society of Finland 58, $45-55$.

Grube, F., 1981. The subdivision of the Saalian in the Hamburg region. Mededelingen Rijks Geologische Dienst 34, 15-25.

Grönlund,T., 1991. The diatom stratigraphy of the Eemian Baltic Sea on the basis of sediment discoveries in Ostrobothnia, Finland. Geological Survey of Finland Report of investigation $102,26 \mathrm{pp}$.

Hedberg, H.D., 1976. International stratigraphic guide. Wiley Interscience. J. Wiley \& Sons: New York 200p.

Hirvas, H., 1991. Pleistocene stratigraphy of Finnish lapland. Bulletin of the Geological Survey of Finland 354, 123pp.

Hirvas, H. \& Kujansuu, R., 1979. On glacial, interstadial and interglacial deposits in northern Finland. IGCP, project 73/1/ 24. Quaternary glaciations in the northern hemisphere. Report $5,146-164$.

Holland, C.H., 1986. Does the golden spike still glitter? Journal of the Geological Society of London 143, 3-21.

Korpela, K., 1969. Die Weichsel-Eiszeit und ihre Interstadial in Peräpohjola (nördliches Nordfinnland) im Licht von submöranen Sedimenten. Annales Academiae Scientiarium Fennicae Series A III 99, 108pp.

Lüttig, G., 1965. Interglacial and interstadial periods. Journal of Geology 73, 579-591.

Mangerud,J., 1991. The Last interglacial/glacial cycle in northern Europe. In: Shawe, L.C.K. \& Cushing, E.J. (eds.) Quaternary landscapes.

Menke,B., 1968. Beiträge zur Biostratigraphie des Mittelpleistozäns in Norddeutschland. Meyniana 18, 35-42.

Nenonen, K., 1986. Orgaanisen aineksen merkitys moreenistratigrafiassa. Geologi 38, 41-44.

Niemelä, J. \& Tynni, R., 1979. Interglacial and interstadial sediments in the Pohjanmaa region, Finland. Geological Survey of Finland Bulletin 302, $1-48$.

Nystuen, J.P. (ed.), 1989. Rules and recommendations for naming geological units in Norway. Norsk Geologisk Tidsskrift 69 (Supplement 1) $111 \mathrm{pp}$.

Penck, A. \& Brückner, E., 1901-9. Die Alpen im Eiszeitalter. Leipzig 1199pp.

Saarnisto, M. \& Peltoniemi, H., 1984. Glacial stratigraphy in Kainuu, eastern Finland. Fennia 162, 163-199.

Ter Wee, W.M., 1983. The Saalian Glaciation in the Netherlands. 
In: Ehlers, J. (ed.) GlacIal deposits of north-west Europe. 405-412. Balkema: Rotterdam.

Turner, C., 1970. The Middle Pleistocene deposits at Marks Tey, Essex. Philosophical Transactions of the Royal Society of London B 257, 373-440.

Van der Heide, S. \& Zagwijn, W.H., 1967. Stratigraphical nomenclature of the Quaternary deposits of the Netherlands. Mededelingen van de Geologische Stichting Nieuwe Serie 18, 23-29.

Van der Vlerk, I.M., 1953. The stratigraphy of the Pleistocene of the Netherlands. Koninklijke Nederlandse Akademie van Wetenschappen. Proceedings B 56, $34-44$.

Van der Vlerk, I.M., 1957. Pleistocene correlations between the Netherlands and adjacent areas: a symposium. Conclusion. Geologie en Mijnbouw (Nieuwe Serie) 19, 310-312.

Van der Vlerk, I.M. \& Florschütz, F., 1953. The palaeontological base of the subdivision of the Pleistocene in the Netherlands. Verhandelingen der Koninklijke Nederlandse Akademie van Wetenschappen. 20, 2, 1-58.

West, R.G., 1957. Interglacial deposits at Bobbitshole, Ipswich. Philosophical Transactions of the Royal Society of London B 241, 1-31.

West, R.G., 1963. Problems of the British Quaternary. Proceedings of the Geologists Association 74, 147-186.

West, R.G., 1984. Interglacial, interstadial and oxygen isotope stages. Dissertationes Botaniceae 72, 345-357.

West, R.G., 1989. The use of type localities and type sections in the Quaternary with especial reference to East Anglia. In: Rose,
J. \& Schlüchter, C. (eds.) Type sections. 3-10 Balkema: Rotterdam.

Woldstedt, P., 1929. Das Eiszeitalter. Ferdinand Ecke Verlag: Stuttgart 406p.

Woillard, G., 1975. Recherches palynologique sur le Pléistocène dans l'est de la Belgique et dans les Vosges lorraines. Acta geographia lovaniensia 14, 118p.

Woillard, G., 1978. Grande Pile peat bog: a continuous pollen record for the last 140,000 years. Quaternary Research 9, 121.

Zagwijn,W.H., 1960. Aspects of the Pliocene and Early Pleistocene vegetation in the Netherlands. Geologische Stichting Mededelingen (C-III-1) 5, 78p.

Zagwijn, W.H., 1973. Pollenanalytic studies of Holsteinian and Saalian beds in the northern Netherlands. Mededelingen van de Rijks Geologische Dienst 24, 139-156.

Zagwijn,W.H., 1985. An outline of the Quaternary stratigraphy of the Netherlands. Geologie en Mijnbouw 64, 17-24.

Zagwijn, W.H., Montfrans, van H.M. \& Zandstra, J.G., 1971. Subdivision of the 'Cromerian' in the Netherlands: pollen analysis, palaeomagnetism and sedimentary petrology. Geologie en Mijnbouw 50, 41-58.

Zubakov, V.A. \& Borzenkova, I.I., 1990. Global palaeoclimate of the Late Cenozoic. Developments in palaeontology and stratigraphy 12. Elsevier: Amsterdam. 456 pp.

Received and accepted October 7, 1992 